FedUni ResearchOnline http://researchonline.federation.edu.au

This is the author's accepted version of the following publication: Clark, Roger. The John Creedy economics collection: A donation of significance [online]. History of Economics Review, No. 60, Summer 2014: 101-104. Availability:

<http://search.informit.com.au/documentSummary; $\mathrm{dn}=19723413118$ 3778;res=IELAPA > ISSN: 1037-0196. [cited 10 Jul 15].

The version displayed here may differ from the final published version. The final publication is available at: http://search.informit.com.au/fullText; $d n=197234131183778 ;$;res=IELAPA

Copyright 2015 History of Economic Thought Society of Australia. 


\title{
THE JOHN CREEDY ECONOMICS COLLECTION : A DONATION OF SIGNIFICANCE
}

\author{
A talk given by Roger Clark, Acquisitions Librarian Federation University Australia, on 10 April \\ 2014
}

I can see the headline already "Librarian talks about donation of books".... I hope this little talk won't be quite as boring as that, but I guess the proof will be in the pudding. My name is Roger Clark, and I am the Acquisitions Librarian here at FedUni.

Welcome to the Geoffrey Blainey Research Centre, home to part of the working collections of that great historian, now joined by this other magnificent collection which we are here to celebrate.

University Librarian Leeanne Pitman and HETSA President Alex Millmow have asked me to say a few words about the John Creedy Economics Collection, and I'll do that, from both a professional and a personal perspective.

The Acquisitions Librarian's job is to manage a collection that meets the needs of the students and staff of the institution - we don't get to buy what we like. We also have to be good at saying "no" - mostly "no" to people offering us books for nothing. "Roger, l've just got someone on the phone who wants to talk about a donation".... words that often portend a more or less extended explanation as to why the Library doesn't need extra copies of this or that outdated work, or that books that have sat in a garage for 30 years probably aren't in the best condition, and no, I don't know anyone who'd buy them. There is a lot of work quite often for very little gain, but there is a lot to lose in a public relations sense if you get these encounters wrong.

And then you get donations like Professor Creedy's. I'm sure John Creedy needs no introduction to people here - Truby Williams professor of Economics at the University of Melbourne, his output of work is astonishing - the collection here holds over 50 works which he has authored or edited, and that is only his monographic output (and not even complete at that). I well remember walking through the door of Professor Creedy's office for the first time and seeing his collection - while introducing myself my mind was reeling. The bibliophile in me immediately realised that his was no ordinary collection of academic books.

All book collections tell a story beyond the content of the volumes on the shelves, and the Creedy Collection is no different. Browsing through, you get a sense of which writers are held in high esteem by Professor Creedy, and those from whom he felt he only needed the basics on his own shelves. Authors such as Alfred Marshall, A.C. Pigou and Philip Wicksteed are represented by nearly all their works, which in some cases are hard to find, and no doubt are here as a result of many patient hours spent searching shelves in bookshops. The compulsion of a collector to get the final piece in the puzzle is well illustrated in the Creedy Colleciton by the Philip Wicksteed titles held here. It has been written of Wicksteed (by Lionel Robbins) that "His various books, never issued in large editions, have become extremely rare, and are greatly 
sought after". The Creedy Collection has a good selection Philip Wicksteed titles, including a copy of the rare title Dante : six sermons signed and inscribed by the author.

Some book collections can be characterised by the efforts of the collector to get the earliest edition, some collections can be characterized by getting the complete output of particular authors, some can be characterized by the coverage of a subject, and some can be characterized by who originally owned the copies of the works in the collection - the Creedy Collection collection has all of those characteristics.

We can see the progression of Professor Creedy's career within these shelves. We see the cheap paperback or ex-library copy of a book that he might have purchased when a student, or very early in his academic career. This might sit next to a first edition or finer binding that was purchased later on, which might have one of his wonderful bookplates inserted. That might again sit next to another edition, signed by the author, or from the collection of another wellknown figure such as Richard Downing, N.F. Hall, James Meade and others. We can see the progression of Professor Creedy's thought by looking at his own publications sitting within this collection, and we can see the growth of his influence by the dedications to him on many of the newer books that sit on these shelves.

Professor Creedy has, by wit, association and his own effort, managed to gather some great signed copies which we are now fortunate to hold. Examples include Arthur Salter's Recovery: the second effort signed by the author with a dedication to Sydney and Beatrice Webb, Essays in political and moral philosophy signed by the author T.E. Cliffe Leslie, H.D.

Dickinson's Institutional revue inscribed "To Dr. E. Cannan from the author with gratitude 1932". One of the stories told me by Professor Creedy during my first visit concerned the book The economics of imperfect competition by Joan Robinson. This is a title that is held in duplicate here, but one copy is more important than the other - it's signed by the author. Some of you will no doubt know Joan Robinson by reputation, and apparently that reputation is quite fearsome. This book is wonderfully illustrative of the collection as a whole - Joan Robinson's daughter arranged for it to be signed for John Harper, and his wife Marjorie, who is the author of Douglas Copland : scholar economist, diplomat, gave it to Professor Creedy on John's passing.

What is the value of having such signed and association copies? It is an intangible value, but in a collection such as this, it is a real value. It gives us an indication, or if you will a trajectory, of the heritage of a subject. A book with a hand-written dedication gives us an idea of the esteem with which the author held the person to whom they wrote the dedication. The fact that Professor Creedy sought out books previously owned by N.F. Hall, James Meade and others shows us the value he placed in their work and thought. That these books are now in his collection show us his connection to them. The books dedicated to Professor Creedy then continue that heritage. The links and connections between these books can tell the astute browser something about how the history of economic thought has been developed and passed down through its scholars. 
There is a bibliographic value in this collection - given the wide date range and coverage of what's on the shelves, it shows us in some ways the history of the importance of economics as a discipline, with its mix of pamphlets, academic tomes and popular editions, it shows how the subject moved into the mainstream of academic life, and then to the wider world.

Of course there is great value as well in the collection in the contents of the works, and that they are all here in the one place. There are approximately 4,000 volumes in the collection, and within them can be found the history of economics as a discipline. As well as the works of all major classical and neoclassical economists, the collection is very strong in the areas of Public Economics, Income Distribution and Poverty, Demography and Labour Economics, the Economics of War, National Income, and of course the History of Economic Thought.

4,000 volumes is a lot. Talking about this donation, I thought I might spend a few moments discussing how libraries deal with them, and what they mean to us. This donation was enabled via the Federal Government's Cultural Gifts Program, which enables donors to get a reasonable compensation for their generosity. As you might expect, fulfilling the criteria involves dealing with lots of bureaucracy, including valuations. The University employed as valuer one of Australia's premier bookmen, John Arnold, who wrote of this collection "In over twenty years of valuing and over forty years of involvement in the book trade and library world, I believe the Creedy Collection to be one of the best, if not the best, formed single collection in wide subject area that I have seen." Once the valuation and paperwork is done and is approved by the Cultural Gifts Committee, then it's just a matter of picking up the books and getting them on the shelves.....

This is not as simple as it sounds. In Professor Creedy's office (actually offices - he needed two, to house the collection), the books were shelved with harmony and care, as a bibliophile would, with authors and related works together in sections that led logically from one to the other. This, as you may well know, is not something that Libraries, or the Dewey Decimal System does well - we are subject-based. Take William Stanley Jevons for example - in a personal library all books written by him would be shelved together - in a university library his Essays in Economics would be shelved half a building away from The principles of science : a treatise on logic and scientific method. We wanted as much as possible to replicate how these books would look on personal shelves, so the cataloguers here at Federation University have endeavoured to do so where possible. This process took the Library over a year to complete.

What is the value to a University Library of such a collection? 95\% of the titles in this donation are "new" to our collection, which is an obvious value. The types of titles in the collection are important too - personal libraries might be limited by the taste of their creators, but they contain, as this one does, many rare, hard-to-get works that University Libraries by their nature do not collect. Then there is the value for us as a new University in having an eminent academic give us his collection, where it will hopefully be the spawn of many activities - it has drawn you people here today, and students have already started using it in their studies. 
There is another, perhaps sadder (to me anyway) reason that this collection has value. And that is in this age of Ipads and eBooks, of streaming videos and instant chat, will we ever see these sorts of collections again? Will we be able to point to a great intellectual figure and say "here are the works that influenced them and made them the person they were"? I fear not. I hasten to add that I am not a Luddite, and fully grasp the advantages that modern technology gives us to fulfil our students needs wherever those students may be. However I do wonder how many of the titles in this collection are or will be available digitally into the future.

So, in housing the John Creedy Economics Collection, we not only are preserving a fount of economic history, we are preserving a history of 20th century of academic life, the connections and links that existed between economists, and even the history of publishing. And that is surely something to celebrate.

Thank you. 